Pressure Sores - Clinical Practice and Scientific Approach 
To my daughter Laetitia 


\title{
PRESSURE SORES - Clinical Practice and Scientific Approach
}

\author{
Edited by
}

\author{
Dan L. Bader \\ Department of Materials \\ Queen Mary College, University of London
}

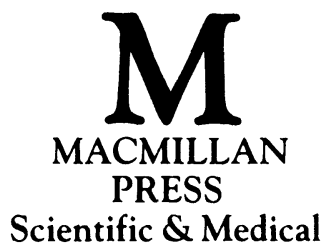


(C) The editor and contributors 1990

Softcover reprint of the hardcover 1st edition 1990 978-0-333-46178-5

All rights reserved. No reproduction, copy or transmission of this publication may be made without written permission.

No paragraph of this publication may be reproduced, copied or transmitted save with written permission or in accordance with the provisions of the Copyright, Designs and Patents Act 1988, or under the terms of any licence permitting limited copying issued by the Copyright Licensing Agency, 90 Tottenham Court Road, London W1P 9HE.

Any person who does any unauthorised act in relation to this publication may be liable to criminal prosecution and civil claims for damages.

First published 1990 by

THE MACMILLAN PRESS LTD

Houndmills, Basingstoke, Hampshire RG21 2XS

and London

Companies and representatives

throughout the world

ISBN 978-1-349-10130-6 ISBN 978-1-349-10128-3 (eBook)

DOI 10.1007/978-1-349-10128-3

A catalogue record for this book is available from the British Library.

Reprinted 1992 


\section{Contents}

Foreword Robert B. Duthie ix

Preface $x i$

The Contributors xiii

\section{PART I CLINICAL ASPECTS OF PRESSURE SORES}

1 The Importance of Pressure Sores in Total Health Care James Robertson, Ian Swain and Ian Gaywood 3 Introduction - An Overview 3

Pressure Sores and the Concept of Tissue Viability 6

Tissue Viability Parameters 9

Pressure Sores and Wound Healing - Patient Support Systems $\quad 10$

Wound Care $\quad 11$

Managerial Aspects of Sores $\quad 12$

The Tissue Viability Society 12

2 Pathogenesis of Pressure Sores

$\begin{array}{ll}J . T . S c a l e s & 15\end{array}$

Introduction $\quad 15$

Structure and Function of Human Skin 16

Causation of Pressure or Distortion Sores 19

3 Pressure Sores: Clinical Aspects of Their Cost, Causation and Prevention

Brian Livesley $\quad 27$

An Expensive Epidemic $\quad 27$

Practical Management and Presdisposing Medical Conditions 28

Factors Predisposing to Pressure Sores 31

Relieving Pressure $\quad 32$

4 The Economics of Pressure Sore Prevention

Pam Hibbs 35

The Cost of Pressure Sores 35

The Cost of a Prevention Plan for a Health District 39

Education 41

5 Current Management for the Prevention of Pressures Sores

Rosemary A. Crow and Michael Clark 
Introduction $\quad 43$

Identifying the Risk of Developing Pressure Sores 43

Selecting Treatment to Prevent Pressure Sores 46

Monitoring the Patient's Progress 49

Strategy to Ensure Good Practice $\quad 49$

\section{PART II EXPERIENCES IN VARIOUS CLINICAL DISCIPLINES}

6 Orthopaedics

Christopher Bulstrode $\quad 55$

Introduction $\quad 55$

Present Attitudes $\quad 55$

Incidence $\quad 55$

$\begin{array}{ll}\text { Causation } & 57\end{array}$

7 Geriatric Medicine

$\begin{array}{ll}M . \text { Bliss } & 65\end{array}$

Incidence $\quad 65$

$\begin{array}{ll}\text { Aetiology } & 65\end{array}$

Pathology $\quad 66$

$\begin{array}{lr}\text { Prognosis } & 69\end{array}$

$\begin{array}{lr}\text { Prevention } & 69\end{array}$

Healing Pressure Sores $\quad 75$

8 The Severely Disabled

George Cochrane $\quad 81$

$\begin{array}{ll}\text { Definition } & 81\end{array}$

Diseases and Disorders in which Risks are High $\quad 81$

$\begin{array}{ll}\text { Prophylaxis } & 87\end{array}$

Treatment of an Established Pressure Sore $\quad 92$

9 Spinal Injury

$\begin{array}{ll}J . R \text {. Silver } & 97\end{array}$

Historical Background $\quad 97$

Pathogenesis $\quad 99$

The Long-term Effects of Pressure Sores 109

10 Reconstructive Surgery

Christopher Khoo and Bruce N. Bailey 117

$\begin{array}{ll}\text { Introduction } & 117\end{array}$

General Plan of Treatment $\quad 117$

The Problem of Recurrence 118

The Development of Reconstructive Surgery 119

Principles of Flap Design $\quad 121$ 
Surgical Management

Pressure Sores in Specific Sites

\section{PART III SCIENTIFIC ASPECTS OF PRESSURE SORES}

\section{Cellular Responses to Tissue Distortion}

Terence J. Ryan

Introduction

Cellular Responses to Mechanical Forces

Tissue Organisation and the Transmission of Mechanical

Forces

How are Biochemical Signals Induced by Mechanical Forces? 146

12 Microvascular Mechanisms in Stasis and Ischaemia

C. C. Michel and Hilary Gillott

Introduction

Reactive Hyperaemia

The Veni-Arteriolar Response

Partial Arterial Occlusion and Venous Congestion 158

Microvascular Responses to Tissue Compression $\quad 159$

Reperfusion Failure and Reperfusion Injury

13 The Metabolic Basis of Wound Healing

A. W. Goode

Introduction

Biochemical Components of Healing 165

The Phases of Healing

The Measurement of Wound Healing

14 Biomechanics of Tissue Distortion and Stiffness by Magnetic Resonance Imaging

Steven I. Reger, Thomas F. McGovern and Kao Chi Chung

Introduction

Methods

Results

Conclusions

15 Effects of Compressive Loading Regimens on Tissue Viability

Dan L. Bader

Introduction

Effects of Prolonged Loading

Discussion 
16 Effects of Mechanical Stresses on Lymph and Interstitial Fluid Flows

Narender P. Reddy

Introduction

Physiology of the Lymphatic System 206

Effects of Mechanical Stresses on Regional Lymph Flow 213

Effects of Mechanical Stresses on Interstitial Fluid Flux 215

\section{PART IV TECHNOLOGICAL SYSTEMS FOR PATIENT MONITORING}

17 Ischial Pressure Distribution Under the Seated Person

Dan L. Bader and M. B. Hawken

Introduction 223

The Performance of Selected Support Cushions 225

Discussion 231

18 Pressure Management and the Recumbent Person

Thomas A. Krouskop, Susan L. Garber and Philip Noble 235

Introduction 235

Limitations of Biomechanical Studies of Tissue Breakdown 235

General Medical Condition 237

Considerations in Selecting Support Surfaces 239

Patient Diagnosis and Lifestyle Considerations 246

19 Movement Studies During Sleep

J. C. Barbenel 249

Introduction 249

Techniques for the Measurement of Movements in Bed 250

Movement Patterns 254

Mobility and Pressure Sore Risk 256

20 Remote Monitoring of Wheelchair Sitting Behaviour

Martin W. Ferguson-Pell, Debra E. Hurwitz, Thomas G.

Burn and R. Masiello

Introduction 261

Design Considerations 263

Performance of Monitoring System 267

Discussion $\quad 271$

$\begin{array}{ll}\text { Index } & 275\end{array}$ 


\title{
Foreword
}

\author{
Robert B. Duthie, CBE, MA, ChM, FRCS
}

This is a first. This textbook deals with one of the major scourges of mankind, namely the pressure sore.

All aspects - whether in the physical and mental suffering of the involved individual, or in the economics, or in the understanding of the basic phenomena behind the lesion, or in its causation, recognition of presentation and improved treatment modalities - are examined critically and commented upon authoritatively by many experts.

Five per cent of all hospital inpatients, i.e. 30000 per year, have developed a pressure sore either just before, during or after admission. There are probably even greater numbers in the community.

Twenty-one variables are described which can now be recognised to identify, with a 98 per cent accuracy, those at risk. All health care staff must be taught to distinguish as many of these variables as possible, for example general and systemic conditions of the patient, local conditions of malnutrition, blood supply, abnormal pressures and lack of ability to shift pressures when required. Once these factors have been discerned, steps should be taken to prevent or improve them.

In addition there are several excellent scientific chapters describing known sensors of measurement, techniques of nursing, positioning and splinting.

However, the field of pathophysiology behind the pressure sore is extraordinary complex and diverse and this too has been brought out clearly by several authors.

An excellent chapter for nurses is included which should however also be required reading for all medical students, housemen and indeed consultants. With such a galaxy of authors, including clinicians, epidemiologists and scientists, there must always be some overlap in data and in expression. But this is a multi-disciplinary subject, each discipline with its own language, stretching from a list of homeopathy lotions to the hard science of measuring tissue oxygen levels - for such measurements in absolute terms are required to delineate when cell necrosis occurs at the various anatomical sites.

The fashion of medicine, with all its financial support, rushes on and leaves in its wake the hard core of clinical conditions, e.g. pain, fractures and pressure sores, all producing long-drawn-out and chronic morbidities. This book brings a new look at the field of pressure sores, and highlights 
how much more research is required and how badly it is needed. I recommend it most seriously to all members of the health care team. 


\section{Preface}

It was with great enthusiasm but not a little trepidation that I embarked on this project. Its major appeal was in its opportunity to develop a structure for a book on pressure sores and select those authors whom I considered most appropriate for the task. This involved lengthy telephone calls with proven experts on both sides of the Atlantic.

There have been several excellent volumes covering the subject area. One such book, Bed Sore Biomechanics, published in 1976 by Macmillan, was based on a meeting held at Strathclyde University. Its influence on both the clinical and the scientific understanding of the problem can not be underestimated and is reflected in its many citations in the current volume. My brief permitted me to extend the discussion to include disciplines that have not always been considered important in previous treatises on the subject.

The book has been conveniently divided into four parts involving the clinical, scientific and technological aspects of the problem. The first five chapters consider the general and practical aspects of the subject, with topics ranging from incidence and economics to predictive scales for identifying subjects at risk. These are followed by a series of chapters (6-10) where clinical specialists describe the problems of pressure sores as related to critical groups within the hospital population. Chapters 11-16 discuss the understanding of the normal and pathological processes in the light of basic biological and physical sciences. The last four chapters describe technological solutions to assess subject performance on existing support systems.

In editing this book, I have attempted to avoid unnecessary repetition. However, in some instances certain messages have been retained between chapters. These include the importance of preventive measures and pressure relief for those subjects at risk of developing pressure sores.

The format of the book has been designed to accommodate a wide readership. This will range from individuals involved directly with patient care and clinicians prescribing prophylactic measures to laboratory-based scientists interested in biological control mechanisms. The clinical problem, being ubiquitous in nature, crosses international boundaries and I hope that overseas readers will be able to convert the UK incidences and costs to their own experiences.

My interest in the subject was initiated at postgraduate level under the supervision of Dr Peter Bowker and blossomed during my eight years at the Oxford Orthopaedic Engineering Centre. I am particularly grateful to 
its director, Mr Derek Harris, for his continued support during this period. Finally I must acknowledge the contributions of Ms Jan Knight and $\mathrm{Mr}$ David Grist, who provided the assistance and necessary drive when deadlines had to be kept.

London, April 1989

D.L.B. 


\section{The Contributors}

\author{
D. L. Bader \\ Department of Materials \\ Queen Mary College \\ University of London \\ London E1 4NS \\ UK
}

\section{B. Bailey}

Consultant Plastic Surgeon

Stoke Mandeville Hospital

Aylesbury HP21 8AL

UK

\section{J. C. Barbenel}

Bioengineering Centre

University of Strathclyde

Glasgow G4 0NW

UK

\section{Bliss}

Consultant Geriatrician

Hackney Hospital

London E9 6BE

UK

\section{Bulstrode}

Consultant Orthopaedic Surgeon

Nuffield Orthopaedic Centre

Oxford OX3 7LD

UK

T. G. Burn

Centre for Rehabilitation

Technology

Helen Hayes Hospital

New York State 10993

USA
K. C. Chung

Rehabilitation Engineering Centre

University of Virginia

Virginia 22903

USA

G. Cochrane

Medical Director

Mary Marlborough Lodge

Nuffield Orthopaedic Centre

Oxford OX3 7LD

UK

M. Clark

Nursing Practice Research Unit

University of Surrey

Guildford GU2 5XH

UK

R. Crow

Nursing Practice Research Unit

University of Surrey

Guildford GU2 5XH

UK

R. B. Duthie, CBE

Nuffield Department of

Orthopaedic Surgery

University of Oxford

Oxford OX3 7LD

UK

M. Ferguson-Pell

Centre for Rehabilitation

Technology and

Orthopaedic Engineering and

Research Centre

Helen Hayes Hospital

New York State 10993

USA 
S. L. Garber

Department of Rehabilitation and Physical Medicine

Baylor College of Medicine

Texas 77030

USA

I. Gaywood

Department Rheumatology and Rehabilitation

Salisbury General Hospital

Salisbury SP2 7SX

UK

H. Gillott

Department of Physiology and Biophysics

St Mary's Hospital Medical School London W2 1PG

UK
A. W. Goode
Consultant Surgeon
London Hospital
London E1 1BB
UK

M. B. Hawken

Department of Neurology

London Hospital

London E1 1BB

UK

P. Hibbs, OBE

Chief Nursing Officer

St Bartholomew's Hospital

London EC1A 7BE

UK

D. E. Hurwitz

Centre for Rehabilitation

Technology

Helen Hayes Hospital

New York State 10993

USA
C. Khoo

Consultant Plastic Surgeon

Wexham Park Hospital

Slough SL2 4HL

UK

T. A. Krouskop

Departments of Rehabilitation and Physical Medicine

Baylor College of Medicine

Rehabilitation Engineering

Department

The Institute for Rehabilitation and Research

Houston

Texas 77030

USA

B. Livesley

Chair of the Care of the Elderly (Geriatrics)

University of London

Charing Cross and Westminster Medical School

London W6 8RP

UK

T. F. McGovern

Department of Musculoskeletal

Research

The Cleveland Clinic Foundation

Cleveland

Ohio 44106

USA

R. Masiello

Centre for Rehabilitation

Technology

Helen Hayes Hospital

New York State 10993

USA 
C. Michel

Department of Physiology and

Biophysics

St Mary's Hospital Medical School

London W2 1PG

UK

P. Noble

Division of Orthopaedic Surgery

Baylor College of Medicine

Houston

Texas 77030

USA

N. Reddy

Biomedical Engineering

Department

University of Akron

Ohio 44325

USA

S. Reger

Department of Musculoskeletal

Research

The Cleveland Clinic Foundation

Cleveland

Ohio 44106

USA
J. Robertson

Consultant

Department of Rheumatology and Rehabilitation

Salisbury General Hospital

Salisbury SP2 7SX

UK

T. Ryan

Consultant

Department of Dermatology

The Slade Hospital

Oxford OX3 7JH

UK

J. T. Scales, OBE

Department of Research in Plastic Surgery

Mount Vernon Hospital

Northwood HA6 2RN

UK

J. Silver

Consultant

Stoke Mandeville Hospital

Aylesbury HP21 8AL

UK

I. D. Swain

Department of Medical Physics

Odstock Hospital

Salisbury SP2 8BJ

UK 